\title{
PERCEPTION OF ABAKALIKI RESIDENTS ON SOCIAL MEDIA COVERAGE OF COVID-19 PANDEMIC: IMPLICATION FOR CRISIS MANAGEMENT IN NIGERIA
}

\author{
Dr. Christiana Ogeri Chukwu ${ }^{1}$ and Raphael Abumchukwu Ekwunife ${ }^{2}$ \\ ${ }^{1}$ Department of Mass Communication, Faculty of Social Sciences,Alex Ekwueme Federal \\ University Ndufu Alike Ebonyi State Nigeria \\ ${ }^{2}$ Department of Mass Communication, College of Arts and Social Sciences, Evangel \\ University Akaeze, Ebonyi State Nigeria
}

Cite this article:

Chukwu C.O., Ekwunife R.A. (2022), Perception of Abakaliki Residents on Social Media Coverage of Covid-19 Pandemic: Implication for Crisis Management in Nigeria. British Journal of Mass Communication and Media Research 2(1), 54-70. DOI: 10.52589/BJMCMRUUSOSE3K.

\section{Manuscript History}

Received: 23 Aug 2021

Accepted: 17 Sept 2021

Published: 26 Jan 2022

Copyright $\odot 2022$ The Author(s). This is an Open Access article distributed under the terms of Creative Commons AttributionNonCommercial-NoDerivatives 4.0 International (CC BY-NC-ND 4.0 ), which permits anyone to share, use, reproduce and redistribute in any medium, provided the original author and source are credited.
ABSTRACT: The spread of new technological tools have significantly promoted globalization and aided ordinary citizens to become news vendors. These technologies beat checkpoints and have limited quality control standards. This study adopted the survey research design to examine the perception of Abakaliki residents on the coverage of covid-19 pandemic in Nigeria. Findings revealed that many discrepancies exist between news management in the social media and professional journalism. Findings showed that the social media carry lots of news items of public interest which the mainstream media ignore. Also, though the social media is stronger in covering official corruption and bad governance, the absence of checkpoints makes it unprofessional. The study recommended the strengthening of social media for complimentary journalism as well as the keeping of a strong data base of all citizens to check the practice.

KEYWORDS: Social Media, Citizen Journalism, Covid-19 Pandemic, Crisis Management, Fake News 


\section{INTRODUCTION}

\section{Background of the Study}

It is evident that nobody in the present age is oblivious of the covid-19 pandemic that rocked the world terribly in the year 2020. This is particularly true as such a pandemic had not been witnessed within the last century (Ekwunife, Ukeje, Robinson and Kalu, 2020). Both in the developed liberal societies of the north and the developing nations of the south, the coronavirus experience was a bad hit on both the private and public sectors. In the face of the pandemic, so many pieces of information flooded the conventional and social media as regards the epidemiology (how the virus spreads), symptoms, how it kills and the mortality rate, among others. The economic, political, religious, educational and social effect of the virus was not left out as the media framed discussions and debates which had an invincible influence on audience perception and interpretation (Ekwunife, Chukwu, Agha, Ukeje and Anih, 2021; Nwakpu, Ezema and Ogbodo, 2020).

Researchers (Okunna and Omenugha, 2012; Ekwunife et al, 2020 and Bittner 1989) have observed that the mass media has a significant role to play in determining audience interpretation of social issues through media advocacy and framing. This is exemplified in the agenda-setting function of the media, whereby the media gives attention and prominence to the coverage of some social events while neglecting others. Aside from this prominence, the language of presentation is a factor that influences audience perception.

During the pandemic, the social media's coverage of the pandemic is significant; hence, Oberiri and Elif (2019) observe that the use of social media in crisis management is in its growing stage. This is informed by its special nature characterized by the absence of checkpoints, gatekeeping and bureaucracy (Ekwunife, Kalu, Ukeje and Eguavoen, 2020). The absence of checkpoints in social media use has given rise to the dissemination of doctored content, fake news and misinformation. Amidst the issues that threatened life during the pandemic, the influx of information in social media has been observed by researchers as a phenomenon that led to information overload, infodemic and an increase in tension. Examples of overt dysfunctions of social media could be seen in the social media coverage of the farmers-herders clash in Nigeria, the Kaduna killings of 2018, the past xenophobia crisis in South Africa (Ekwunife et al, 2020), insecurity situations in Nigeria and of course, the first wave of the coronavirus pandemic experienced globally in 2020.

It is, therefore, the focus of this study to examine the perception of Abakaliki residents on the social media coverage of the covid-19 pandemic to see the implication of this coverage in crises. Being a time of crisis, this study is poised to determining how the social media information management of covid-19 affected the Abakaliki residents. 


\section{Research Objectives}

The objectives of the study are to:

i. Find out the commonest social media platforms used by Abakaliki residents which resulted in infodemic during the pandemic.

ii. Ascertain the level of Abakaliki residents' believability in the covid-19-related messages disseminated through social media.

iii. Determine the influence of covid-19-related messages in the social media and Abakaliki residents' response to covid-19 protocols.

\section{Hypotheses}

The following hypotheses were formulated and tested in the study:

H01: There is no significant relationship between social media platforms and infodemic during the pandemic.

H02: There is no statistical difference between covid-19 related messages in the social media and Abakaliki residents' response to covid-19 protocols.

\section{LITERATURE/THEORETICAL UNDERPINNINGS}

\section{Social Media: A Discourse}

Social media are referred to as unconventional media. They are unconventional because their modus operandi is a shift from those of the mainstream media such as radio and television. Social media are channels through which users create, share and or exchange information, ideas and views. They are facilitated by the new media technology which enables interaction in virtual communities of networks. Ndolo (2011) and Ekwunife et al (2020) observe that the internet is the tool that powers the new media which create the platform for virtually social interactions. As unconventional media, social media enable ordinary citizens who are not trained journalists to participate actively in the job of information gathering and dissemination. This practice has significantly promoted the concept of citizen journalism whereby individuals in the streets do the work of trained journalists unprofessionally (Oberiri, 2016). Despite this observed unprofessionalism, researchers (Obi-Ani, Anikwenze and Isiani, 2020) have noted that social media as a tool has accorded citizens privy to information without hitches; however, it has greatly been used to advance misinformation and circulate unverifiable and deceptive content to the citizens.

There are various social media outlets that users employ. Some of them are blogs which are platforms for casual dialogue and discussions on a given topic. Twitter is a form of social networking /micro-blogging outlet where groups and individuals stay connected in the exchange of short status messages having not more than 140 characters, hence, a user is said to 'tweet'. Facebook has been adjudged the world's largest social network with over 2.6 billion monthly active users as of 2020 (Tankovska, 2021). It allows a user to create a personal profile and adds other users as friends for the exchange of messages including 
updates of status. Another popular social media platform is Instagram which is a free photo and video sharing app that enables users to apply digital filters, frames and special effects to their photos which can be shared on various social networking sites. YouTube is majorly a video hosting and watching website. Groups of professionals who share similar interests also use a social media outlet- LinkedIn to share information and engage in conversations. Flickr is an image and video hosting website that allows the sharing of photos on Facebook, Twitter and other social networking sites.

With these social media tools and platforms, the dissemination of information has been made easy with a snap of the finger, particularly among technologically inclined youths. As the government of many nations imposed lockdowns that restricted movements and stifled many social activities during the pandemic of 2020, social media became significant tools for engagement and communication in spreading both functional and dysfunctional content. The power of social media is captured in its ability to convey live pictures by video recording of happenings as they occur.

\section{Social Media Coverage of Covid-19 Pandemic}

Unarguably, social media was awash with covid-19 related messages all through the year 2020. From the month of March 2020 which could be called the first phase of the spread of the virus in Nigeria, the spread was low in Africa (Caitlinalder, 2020) (including Nigeria) but the news about the coronavirus flooded social media to the degree that it resulted in information overload (Ekwunife et al, 2020). In the face of this low spread of the virus in Africa, Nigeria was predicted to have the highest number of infections in Africa. This was one of the commonest pieces of information disseminated by social media. The coverage of the coronavirus pandemic in Nigeria is significant since Nigeria ranks among the very top users of social media in the world. The social media being massively used by Nigerians was instrumental in reporting covid-19 related deaths, preventive measures, spread, among others (Nwakpu et al, 2020).

Lacking the gate-keeping process that makes journalism a distinct profession, the covid-19 related information in the social media intentionally or unintentionally were framed and designed to determine how Nigerians responded to media advocacy on the pandemic. For example, while the mainstream media could maintain that the virus was real, several social media contents negated this view. The important question is this, "between the social media messages and those of the mainstream media, which do Nigerians find credible?" This question becomes pertinent as social media seems to have significantly influenced people's behaviour during the pandemic, particularly as people sat back in their homes during the lockdown and married their social media platforms.

Oberiri and Elif (2019) have observed that the coverage of crises by social media is such that fuels tension and other problems due to its poor management of information. In the writing of WHO, Wunderman, University of Melbourne and Pollfish (2021, p.1), the use of social media to report the covid-19 pandemic

...has demonstrated how the spread of misinformation, amplified on social media and other digital platforms is proving to be as much a threat to global public health on the virus itself... enable and 
amplify the current infodemic that continues to undermine the global response and jeopardizes measures to control the pandemic.

The infodemic associated with the social media coverage of the pandemic is mostly spread by the youths who are the most active online users as they interact with an average of 5 social media platforms such as Facebook, Twitter, Instagram, WhatsApp and WeChat. As these platforms allow for content sharing, users can disseminate any message across different platforms, hence, massifying and proliferating the messages on the media space. Certainly, the younger generation sources much of her information from the new media. While the youths are aware of the fake news that characterize social media at all times and during the pandemic, in particular, the fact remains that these young users end up sharing such content on the same platform or across other platforms, either for fun or to keep busy without knowing the implication. Besides, at the peak of the pandemic amidst the infodemic, people did not know what information to doubt and what information to believe. Su et al (2020) are of the view that the media coverage (both the mainstream and the social media) of coronavirus pandemic was characterized by (i) balanced, fact-based and truth-oriented messages, (ii) biased and misleading contents as well as (iii) false and dishonest communication messages.

Inherently, social media coverage of covid-19 is harmful as it has intrinsic deadliness and negativity (Quin, Zhang, and Su, 2020). Following the agenda-setting function of the media which gives attention and prominence to certain events by frequently featuring them in the media amidst other unreported events, the scale and severity of covid-19 brought it to the limelight of the media, thereby making it a sacred cow in journalistic parlance (Ekwunife et al, 2020; Ekwunife et al, 2021). In terms of coverage, both the traditional media and the new media on many occasions have contradicting messages. For example, while the traditional media propagated that the coronavirus had no cure, the social media vehemently shared reports of miracle cures, herbal cures and the Democratic Party hoax. In addition, the message from Dr Stella Immanuel of the United States Hospital which promoted and sustained the conspiracy theory about the virus was entrenched in the social media, and this undermined, not just response by Nigerians but on a global scale. The conspiracy theory of covid-19 was greatly promoted by social media as social media regularly and consistently featured comparative videos of covid-19 patients in the UK, USA, Italy and Nigeria.

Evidently, the covid-19 patients from the international communities like the USA, UK, Italy, among others, were critically gasping for breath while their counterparts in Nigeria looked healthy and comfortable in their isolation centres and hospital beds. A case in point which the mainstream media featured and was made more prominent in the social media was the video of supposed covid-19 patients in Nigeria who left their isolation centre and went on protest, blocking roads in agitation for better attention from the government. This was in sharp contrast to the covid-19 patients in the US for example where medical personnel would always be running helter-skelter to save their lives.

Social media, particularly Facebook and WhatsApp disseminated videos of the citizens in hunger and deprivations amidst the news of numerous palliatives distributed by the federal government. Social media was disposed to reporting other sides of responses to the pandemic which the government neglected or did not do well. A case in point was the endsars protest that followed the end of the covid-19 lockdown in Nigeria (Ekwunife, Opara, Akpan and 
Sunday, 2021). On many occasions, the masses formed their opinions based on these social media presentations because they were convincing and appeared credible. The announcement of the first victim of coronavirus was made through various social media platforms such as Twitter, Facebook among others. Nigeria Centre for Disease Control (NCDC) also utilized social media as a platform to disseminate vital information (Obi-Ani et al, 2020). Covid-19 related information was not only disseminated on social media by ordinary people (citizen journalists). Formal organisations such as NCDC, Mobile Telecommunication Network, World Health Organization, Presidential Task Force on covid-19, among others also used social media to spread useful pieces of information for the safety of the citizens. Updates on the rate of spread, mortality rate, precautionary measures and other information were given through social media. Aside from the advantage of combining the mainstream and social media for effective delivery of covid-19 related information, social media was utilized because of its reach, accessibility, speed of information dissemination and potent influence on the younger generation.

In its information and communication management, social media was used to spread fear, panic and confusion (NCDC, 2020). This appeared to be an uncontrollable variable since the nature of social media permits the spreading of unverified content and fake news without check, fear or caution (Kalu and Ekwunife, 2020). Researchers (Savrum and Leon, 2015) observed that social media worsen social issues by heightening negative impressions on such issues. On social media, the religious perspectives of the covid-19 pandemic gained ground. The pandemic was spotted as a fight against the church, particularly as churches were banned from their usual assembly. The coronavirus was explained as a hoax and a guise to advance the recent technological development of the $5 \mathrm{G}$ network. In social media, the enlightenment about the 5G network was rather poor as the greater percentage's thought of the new technology got swallowed by the viewpoint that people were dying as a result of the introduction of the 5G network. A major proponent of this ideology was Pastor Chris Oyakhilome of Christ Embassy, otherwise called Believers Love World Ministry. According to Adelaku (2020), the religious perspective of the coronavirus greatly carried by the social media argued that it was a ploy to install the 5G network following the lockdown; a tactic to depopulate the church as the Antichrist agenda.

\section{Summary}

In all, the coverage of the covid-19 pandemic via social media could be said to be a coverage that was both functional and dysfunctional. While social media such as Facebook and WhatsApp were used to disseminate covid-19 related information speedily and massively; it also seemed to create panic and tension in the audience. The mass of information in social media led to information overload, and consequently, infodemic. Both the government and private individuals used social media extensively and some information in the social media contradicted others in the mainstream media. By this literature, the use of social media for the coverage of crises, particularly by ordinary citizens who are not trained journalists is found both useful and problematic. 


\section{METHODOLOGY}

The research method deals with how the problems of research are investigated. This is the framework for data collection. Kitzinger (1957) notes that the research design is the plan, structure and strategy of enquiry in order to obtain responses to the research questions and control variance. For this purpose, the survey research method was used. The survey enabled the researcher to elicit direct responses from the respondents through the instrument of the questionnaire. The survey research method was also adopted for this study because the researcher could not sample the opinions of the entire population in the Abakaliki metropolis, hence, the survey research method provided the sampling technique, whereby a limited portion of the population was studied and generalization made.

The population of the Abakaliki metropolis is 134, 102 (World Population Review, 2020). This number comprises of residents in Abakaliki urban which mainly include areas such as Amike-Aba, Kpirikpiri, New Layout, Afikpo Road/Ogoja Road axis and Mile 50. Given the above population, the sample size of the study is 400 . This was determined using the sample size published table (Singh \& Masuki, 2014) which indicates that a sample of 400 is appropriate for a population above 100,000. A sampling of the questionnaire was based on the quota system, whereby the researcher deliberately assigned unequal numbers of questionnaires to different areas of the population based on certain characteristics such as population, location and educational level. The design instrument contained a total of 15 questions structured on a Likert scale of 4 points. The choice of the Likert scale was considered appropriate since the researcher is studying attitude. The quota sampling method was used in determining the number of questionnaires to assign to any particular area of the population. The rationale for adopting this approach was to ensure that the study used the population that has exposure to social media coverage of covid-19. Hence, Amike-Aba which is not at the centre of the metropolis got 70 copies of the questionnaire, followed by Kpirikpiri which got 96. New Layout was assigned 84 copies of the instrument while the Afikpo Road/Ogoja Road axis got 80 copies. Mile 50 was assigned 70 copies. To reach the respondents, the researcher administered some of the questionnaires to respondents from these areas of study at the church through their respective cell fellowships comprising people from those areas. The use of five research assistants from these areas also helped the researcher to distribute other copies to respondents according to the sampling quota. With the help of five research assistants, 400 copies of the questionnaire were administered to the respondents. Collecting the questionnaire, however, was not as easy as distributing them as the responses were not done at the same time. This lengthened the collection for about three weeks. Finally, only 363 copies of the instrument were retrieved. This gave a response rate of $91 \%$. The five research assistants were as well used to collect the instrument from the respondents since they are part of the people and share both the physical and psychological proximity to affect the needed responses.

When the copies of the questionnaire were assembled, each of the four (4) research questions was answered using a set of five (5) relevant questions from the questionnaire. The number of responses per variable was ascertained and shown on a frequency table. The simple percentage was used to present and analyse the demographic data while the section on general information was tabulated and the mean value of each set was calculated using the Likert Scale of 4 point weight. Any result less than 2.5 is rejected while any outcome from 2.5 and above is accepted. 


\section{RESULT/FINDINGS}

\section{Data Presentation}

Data for this research were gathered from the Ebonyians who reside within the Abakaliki metropolis. Demographic data were analyzed using the simple percentage while data on general information were analysed using the mean method. The decision rule accepted any calculated mean value from 2.5 while anything less than that is rejected

Table 1. Analysis of Bio-data of the Sampled Population

\begin{tabular}{|l|l|l|l|}
\hline Case & Item & Frequency & Percentage \\
\hline Gender & Male & 231 & $64 \%$ \\
& Female & 132 & $36 \%$ \\
\hline \multirow{2}{*}{ Age } & Total & $\mathbf{3 6 3}$ & $\mathbf{1 0 0 \%}$ \\
& $18-22$ & 77 & $21 \%$ \\
& $23-27$ & 83 & $23 \%$ \\
& $28-32$ & 92 & $25 \%$ \\
& $33-37$ & 60 & $17 \%$ \\
\hline \multirow{2}{*}{ Education } & $38-$ above & 51 & $14 \%$ \\
& Total & $\mathbf{3 6 3}$ & $\mathbf{1 0 0 \%}$ \\
& PG & 48 & $13 \%$ \\
& Degree & 94 & $26 \%$ \\
& SSCE & 132 & $36 \%$ \\
& FSLC & 65 & $18 \%$ \\
& No formal Education & 24 & $7 \%$ \\
\hline
\end{tabular}

In table one above, $64 \%$ are males while $36 \%$ are females, indicating that there are more male respondents than females as the males appeared more disposed to accepting the research instrument. On the age range, $18-22$ years form $77 \%$ of the sampled population while $23 \%$ shows the age range of $23-27$. The age range of $28-32$ has $25 \%$, the age range of 33-37 has $16 \%$ while 38 and above forms $14 \%$ of the sample. This implies that respondents are composed mostly of youths whose age range is between 28 and 32 years old. Looking at the educational qualification of the respondents, $13 \%$ of the sample has Post-Graduate qualifications, degree holders have 26\%, Senior School Certificate holders have $36 \%$ and $18 \%$ have basic primary education while $7 \%$ have no formal education at all. This indicates that the greater part of the respondents is literate and learned beyond basic education, thus, respondents are competent to respond.

\section{Research Question I}

What are the commonest social media platforms used by Abakaliki residents which resulted in infodemic during the pandemic?

Questions numbers 1,2,3,4 and 5 answered this question. 
Table 2: Mean Responses of Respondents on the commonest social media platforms used by Abakaliki residents which resulted to infodemic during the pandemic

\begin{tabular}{|l|l|l|l|l|l|l|l|l|}
\hline S/N & ITEM & SA & A & D & SD & FX & X & DECISION \\
\hline 1 & I have a smartphone & 211 & 134 & 18 & - & 1282 & 3.53 & Accepted \\
\hline 2 & $\begin{array}{l}\text { Laptop serves me for online } \\
\text { posting }\end{array}$ & 152 & 187 & 17 & 7 & 1210 & 3.33 & Accepted \\
\hline 3 & $\begin{array}{l}\text { I have a personal camera for } \\
\text { image capturing }\end{array}$ & 31 & 40 & 244 & 48 & 780 & 2.15 & Rejected \\
\hline 4 & I have blogs/websites & 79 & 242 & 32 & 10 & 1116 & 3.07 & Accepted \\
\hline 5 & $\begin{array}{l}\text { I am an active } \\
\text { Facebook/Whatsapp user }\end{array}$ & 201 & 106 & 33 & 23 & 1211 & 3.34 & Accepted \\
\hline
\end{tabular}

In table two above, the mean of 3.53 indicates that the majority have smartphones for online journalism and this has a significant impact on crises management. The use of laptops in CJ is supported with a mean value of 3.33 but not as much as the use of smartphones. The capturing of images with a personal camera for online journalism is negated with a mean of 2.15 which shows that the use of a personal camera is not a significant tool used by Abakaliki residents for citizen journalism. Out of the sample, the mean of 3.07 shows that the respondents have access to blogs and websites, while the mean of 3.34 indicates that the respondents are active users of Facebook and Whatsapp platforms which have highly impacted their involvement in citizen journalism.

\section{Research question II}

What is the level of Abakaliki residents' believability in the covid-19 related messages disseminated through social media?

Questions numbers 6,7,8,9 and 10 were used here.

Table 3: Mean Responses of Respondents on the level of Abakaliki residents' believability in the covid-19 related messages disseminated through the social media

\begin{tabular}{|l|l|l|l|l|l|l|l|l|}
\hline S/N & ITEM & SA & A & D & SD & FX & X & DECISION \\
\hline 6 & $\begin{array}{l}\text { I believed the social media message that the } \\
\text { acclaimed coronavirus in Nigeria was not } \\
\text { real }\end{array}$ & 74 & 175 & 38 & 76 & 973 & 2.68 & Accepted \\
\hline 7 & $\begin{array}{l}\text { I adopted the herbal preventive measures } \\
\text { disseminated by the social media }\end{array}$ & 84 & 35 & 104 & 40 & 789 & 2.17 & Rejected \\
\hline 8 & $\begin{array}{l}\text { I believed the coronavirus could not kill } \\
\text { Africans/Nigerians }\end{array}$ & 113 & 125 & 66 & 59 & 1018 & 2.80 & Accepted \\
\hline 9 & $\begin{array}{l}\text { Coronavirus was just a ploy by the ruling } \\
\text { class to achieve some selfish interest }\end{array}$ & 73 & 161 & 100 & 29 & 1004 & 2.77 & Accepted \\
\hline 10 & $\begin{array}{l}\text { I accepted the popular view in social media } \\
\text { that chloroquine was a cure to coronavirus } \\
\text { if it existed }\end{array}$ & 79 & 149 & 100 & 44 & 971 & 2.67 & Accepted \\
\hline
\end{tabular}


In the table above, the mean of 2.68 shows that many of the respondents believed that the coronavirus was not real in Nigeria, and this influenced their dispositions towards the virus and the pandemic. With a mean value of 2.17 , the respondents have not adopted the covid-19 herbal therapies advocated by the social media which shows that they have not accepted every piece of information about covid-19 in social media. The mean of 2.80 shows that the respondents believed that the virus could not kill Nigerians/Africans, hence, did not take some of the media advocacy serious while the mean of 2.77 corroborates that the respondents believed the conspiracy theories disseminated by the social media. The mean score of 2.67 confirms that Abakaliki residents believed that if the virus was real, chloroquine was a cure to it. The implication is that the Abakaliki residents did not take chances concerning the covid19 related messages disseminated on social media.

\section{Research Question III}

What is the influence of the covid-19 related messages in the social media on Abakaliki residents' response to covid-19 protocols?

Questions 11,12,13,14 and 15 were instrumental to answering the question.

Table 4: Mean Responses of Respondents on the Influence of Covid-19 Related Messages in the Social Media on Abakaliki residents' response to covid-19 protocols

\begin{tabular}{|c|c|c|c|c|c|c|c|c|}
\hline $\mathbf{S} / \mathbf{N}$ & ITEM & $\mathbf{S A}$ & $\mathbf{A}$ & D & SD & FX & $\mathbf{X}$ & $\begin{array}{l}\text { DECISI } \\
\text { ON }\end{array}$ \\
\hline 11 & $\begin{array}{l}\text { My movement was unwillingly } \\
\text { restricted in keeping with covid-19 } \\
\text { protocol }\end{array}$ & 88 & 102 & 97 & 76 & 928 & 2.56 & Accepted \\
\hline 12 & $\begin{array}{l}\text { I continued embracing people in spite } \\
\text { of the covid- } 19 \text { messages to desist from } \\
\text { that. }\end{array}$ & 80 & 77 & $\begin{array}{l}13 \\
2\end{array}$ & 74 & 889 & 2.45 & Rejected \\
\hline 13 & $\begin{array}{l}\text { I maintained social distancing during } \\
\text { the covid- } 19 \text { pandemic }\end{array}$ & $\begin{array}{l}10 \\
7\end{array}$ & 116 & 82 & 58 & 998 & 2.75 & Accepted \\
\hline 14 & $\begin{array}{l}\text { I avoided public gatherings during the } \\
\text { coronavirus pandemic }\end{array}$ & 61 & 147 & 71 & 84 & 911 & 2.51 & Accepted \\
\hline 15 & $\begin{array}{l}\text { I maintained regular hand washing with } \\
\text { sanitiser during the covid-19 pandemic }\end{array}$ & $\begin{array}{l}16 \\
6\end{array}$ & 175 & 18 & 4 & $\begin{array}{l}122 \\
9\end{array}$ & 3.39 & Accepted \\
\hline
\end{tabular}

In table four, the mean value of 2.56 indicates that the respondents had their movements restricted, not necessarily of their own willful volition but because of the imposed lockdown. The mean of 2.45 shows that the respondents avoided embrace in as much as they believed the conspiracy theories. The implication is that they did not take chances. With a mean of 2.75 , the respondents maintained social distancing, showing that they were also sceptical of social media advocacy. In the same vein, the value of 2.51 indicates that the Abakaliki residents kept to the social distance protocol. This also shows that they may not have doubted the existence of the virus, or done it out of fear. With a mean value of 3.39, the respondents kept to the washing of hands with an alcohol-based sanitiser. From this table, it is gleaned that though the respondents observed the covid-19 protocols, it was out of fear and scepticism of covid-19 related messages. 


\section{Test of Hypotheses and Data Analysis}

H01: There is no significant relationship between social media platforms and infodemic during the covid-19 pandemic

Here, a Chi-square $\left(\mathrm{X}^{2}\right)$ was used to test the hypothesis and data analysed. Thus;

$$
X^{2}=\left(f_{o}-f_{e}\right)^{2} / f_{e}
$$

Where $f_{o}=$ frequency of the observed data

$f_{e}=$ frequency of the expected values

To calculate the expected frequency, we multiply the total column by the total row and divide it by the grand total.

Table five: Samples Collected

\begin{tabular}{|l|l|l|l|l|l|l|}
\hline Response & Sample 1 & Sample 2 & Sample 3 & Sample 4 & Sample 5 & Totals \\
\hline Agreement & 345 & 339 & 71 & 321 & 307 & $\mathbf{1 3 8 3}$ \\
\hline Disagreement & 18 & 24 & 292 & 42 & 56 & $\mathbf{4 3 2}$ \\
\hline Totals & $\mathbf{3 6 3}$ & $\mathbf{3 6 3}$ & $\mathbf{3 6 3}$ & $\mathbf{3 6 3}$ & $\mathbf{3 6 3}$ & $\mathbf{1 8 1 5}$ \\
\hline & & & & & & \\
\hline
\end{tabular}

Source: 209 field survey

Total in the first row $\quad=\quad 1383$

Total in the second row $\quad=\quad 432$

Total in each column $=363$

Thus, expected frequency $\left(f_{e}\right)$ in the first row $=$

$363 \times 1383 / 1815=502029 / 1815=276.6$

And expected frequency $\left(f_{e}\right)$ in the second column $=$

$$
363 \times 432 / 1815=156816 / 1815=86.4
$$

From table five above, the chi-square $\left(\mathrm{X}^{2}\right)$ table can be set up.

Table Six: Chi-Square $\left(\mathrm{X}^{2}\right)$ Table

\begin{tabular}{|l|l|l|l|l|}
\hline Observed $\left(\mathbf{f}_{\mathbf{o}}\right)$ & Expected $\left(\mathbf{f}_{\mathbf{e}}\right)$ & $\left(\mathbf{f}_{\mathbf{o}}-\mathbf{f}_{\mathbf{e}}\right)$ & $\left(\mathbf{f}_{\mathbf{o}}-\mathbf{f}_{\mathbf{e}}\right)^{\mathbf{2}}$ & $\left(\mathbf{f}_{\mathbf{o}}-\mathbf{f}_{\mathbf{e}}\right)^{\mathbf{2}} / \mathbf{f}_{\mathbf{e}}$ \\
\hline 345 & 276.6 & 621.6 & 386386.56 & 1396.91 \\
\hline 339 & 276.6 & 62.4 & 3893.76 & 14.08 \\
\hline 71 & 276.6 & -205.6 & 42271.36 & 152.82 \\
\hline 321 & 276.6 & 44.4 & 1971.36 & 7.13 \\
\hline 307 & 276.6 & 30.4 & 924.16 & 3.34 \\
\hline 18 & 86.4 & -68.4 & 4678.56 & 54.15 \\
\hline 24 & 86.4 & -62.4 & 3893.76 & 45.07 \\
\hline 292 & 86.4 & 205.6 & 42271.36 & 489.25 \\
\hline 42 & 86.4 & -44.4 & 1971.36 & 22.82 \\
\hline 56 & 86.4 & -30.4 & 924.16 & 10.70 \\
\hline
\end{tabular}


Chi-Square $\left(\mathrm{X}^{2}\right)=1396.91+14.08+152.82+7.13+3.34+54.15+45.07+489.25+22.82$ $+10.70=2196.27$

To calculate the degree of freedom (df):

$($ Row - 1) (Column - 1)

i.e. $(5-1)(2-1)=4 \times 1=4$.

Since $2196.27>11.070$ which is the value of alpha (0.05) in the probability level, it is therefore empirically supported and the null hypothesis $\left(\mathrm{H}_{\mathrm{o}}\right)$ rejected. Hence, there is a significant relationship between social media platforms used by Abakaliki residents and the infodemic during the pandemic.

\section{Test of Hypotheses and Data Analysis}

H02: There is no statistical difference between covid-19 related messages in the social media and Abakaliki residents' response to covid-19 protocols

Here, a Chi-square $\left(\mathrm{X}^{2}\right)$ was used to test the hypothesis and data analysed. Thus;

$X^{2}=\left(f_{o}-f_{e}\right)^{2} / f_{e}$

Where $f_{o}=$ frequency of the observed data

$f_{e}=$ frequency of the expected values

To calculate the expected frequency, we multiply the total column by the total row and divide it by the grand total.

Table Seven: Samples Collected

\begin{tabular}{|l|l|l|l|l|l|l|}
\hline Response & Sample 1 & Sample 2 & Sample 3 & Sample 4 & Sample 5 & Totals \\
\hline Agreement & 190 & 157 & 223 & 208 & 341 & $\mathbf{1 1 1 3}$ \\
\hline Disagreement & 173 & 206 & 140 & 155 & 22 & $\mathbf{6 9 6}$ \\
\hline Totals & $\mathbf{3 6 3}$ & $\mathbf{3 6 3}$ & $\mathbf{3 6 3}$ & $\mathbf{3 6 3}$ & $\mathbf{3 6 3}$ & $\mathbf{1 8 0 9}$ \\
\hline & & & & & & \\
\hline
\end{tabular}

Source: 209 field survey

Total in the first row $\quad=\quad 1113$

Total in the second row $\quad=\quad 696$

Total in each column $\quad=\quad 363$

Thus, expected frequency $\left(f_{e}\right)$ in the first row $=$

$363 \times 1113 / 1815=404019 / 1809=223.34$

And expected frequency $\left(\mathrm{f}_{\mathrm{e}}\right)$ in the second column $=$

$$
363 \times 696 / 1809=252648 / 1809=139.66
$$

From table six above, the chi-square $\left(\mathrm{X}^{2}\right)$ table can be set up. 
Table Eight: Chi-Square $\left(\mathrm{X}^{2}\right)$ Table

\begin{tabular}{|l|l|l|l|l|}
\hline Observed $\left(\mathbf{f}_{\mathbf{o}}\right)$ & \multicolumn{1}{|c|}{ Expected $\left(\mathbf{f}_{\mathbf{e}}\right)$} & $\left(\mathbf{f}_{\mathbf{o}}-\mathbf{f}_{\mathbf{e}}\right)$ & $\left(\mathbf{f}_{\mathbf{o}}-\mathbf{f}_{\mathbf{e}}\right)^{\mathbf{2}}$ & $\left(\mathbf{f}_{\mathbf{o}}-\mathbf{f}_{\mathbf{e}}\right)^{\mathbf{2}} / \mathbf{f}_{\mathbf{e}}$ \\
\hline 190 & 223.34 & -33.34 & 1111.56 & 4.98 \\
\hline 157 & 223.34 & -66.34 & 4401.10 & 19.71 \\
\hline 223 & 223.34 & -0.34 & 0.1156 & 0.00 \\
\hline 208 & 223.34 & -15.34 & 235.32 & 1.05 \\
\hline 341 & 223.34 & 117.66 & 13843.88 & 61.99 \\
\hline 173 & 138.66 & 34.34 & 1179.24 & 8.50 \\
\hline 206 & 138.66 & 67.34 & 4534.68 & 3.86 \\
\hline 140 & 138.66 & 1.34 & 1.80 & 0.01 \\
\hline 105 & 138.66 & -44.4 & 1971.36 & 14.22 \\
\hline 22 & 138.66 & -30.4 & 924.16 & 6.66 \\
\hline
\end{tabular}

Chi-Square $\left(X^{2}\right)=4.98+19.71+0.00+1.05+61.99+8.50+3.86+0.01+14.22+6.66=$ 120.98

To calculate the degree of freedom (df):

$($ Row - 1) (Column - 1)

i.e. $(5-1)(2-1)=4 \times 1=4$.

Since $120.98>11.070$ which is the value of alpha (0.05) in the probability level, it is therefore empirically supported and the null hypothesis $\left(\mathrm{H}_{0}\right)$ rejected. Hence, there is a statistical difference between covid-19 related messages in the social media and Abakaliki residents' response to covid-19 protocols.

\section{DISCUSSION}

The major discussion, significance and objective of this research are such that explains the perception of Abakaliki residents on social media coverage of the covid-19 pandemic. It addresses the influence of social media messages on respondents' responses to the pandemic as well as how the influx of information on the social media platform has generated lots of misinformation, fake news and information overload.

In as much as the mainstream media responded actively in addressing issues related to the covid-19 pandemic, it is evident that there was a lot of information on the social media platform which resulted in what Agba (2002) calls information overload. This is a situation where the recipients of mass media messages are not able to assimilate and internalize the bulk of information in the media as a result of the excessiveness of this information. During the covid-19 pandemic of 2020, covid-19 related information in the social media that influenced the masses bothered on preventive measures, the spread of the virus, mortality rate, survival rate, among others.

From table two, the Abakaliki residents made active use of social media more than the mainstream media in consuming covid-19 related messages. Such common social media tools 
actively used by respondents were Facebook and Whatsapp, and these significantly influenced audience' attitudes and behaviours emanating from too much information in the media, misinformation and fake news as there were so many doctored contents to satisfy some interests. Evidently, these social media tools had the advantage of speed, affordability in terms of cost, reach and flexibility resulting from the absence of checkpoints and gatekeeping. It was easy for residents to manipulate these devices at whatever point and corner. With Facebook and Whatsapp, respondents were easily disposed to creating and sharing covid-19 related messages without restriction.

In table three, it could be gleaned that the residents were significantly influenced by the social media coverage of the covid-19 pandemic. This manifested in their beliefs as shown in the table. Owing to the conspiracy theories about covid-19 that were circulated on social media, Abakaliki residents doubted the reality of the coronavirus. Many reasons were attributed to this coupled with the distribution of palliatives which was seen as means of enriching some purses- an exercise that was done to favour ethnic, religious and social divides. The effect of the social media messages on covid-19 was particularly evident as the responses showed that the greater number of the sample did not believe that Africans/Nigerians are susceptible to the virus. As propagated by social media, responses by the sample showed that the chloroquine cure for coronavirus gained wide acceptance. No wonder the price of chloroquine skyrocketed during the period. Among the items sampled, the only one that did not gain acceptance was the belief about the herbal cure for covid-19.

Table four shows significant compliance with covid-19 protocols by the respondents despite the contradicting information circulated by the social media. This implies that the respondents did not put all their eggs in one basket. While there were contradicting pieces of information in the social media which the respondents believed relatively, the respondents still guarded themselves in relation to keeping with the covid-19 protocols. Findings showed that some of the protocols were kept out of fear and in keeping with state laws, not necessarily as voluntary decisions. For example, observing the lockdown with restricted movement was kept by the respondents against their wishes. Generally, the respondents observed the covid-19 protocols such as avoiding embrace, maintenance of social distancing, hand washing, among others.

\section{Implication to Research and Practice}

This study has a direct bearing on goal 16 of the sustainable development goals which emphasizes the need to ensure strong institutions. The media as an institution must be viable and in charge of information gathering and dissemination through social media. This is particularly significant in a country like Nigeria where the proliferation and prevalence of the new media are biting hard on governance. To arrest this infiltration, the country recently banned Twitter because such a medium has not come under the control of the media as an institution. Until social media comes under rules, regulations and censorship like the mainstream media, the political institution remains unstable, porous and vulnerable. The general public is also at risk. The implication is hydra-headed as the media has a strong link with other institutions such as the political and the cultural institutions. The influence of the media makes or mars the stability of the state. 


\section{CONCLUSION}

This paper has examined the perception of Abakaliki residents on social media coverage of the covid-19 pandemic and looked at the implication on crises management

The study concludes at this point that while social media plays key roles in complimentary journalism, it is not the best in crises management. This owes to the fact that it is a strong purveyor of fake news which heightens tension among recipients in a time of crisis. The study concludes that social media was highly contributory to the confusion among the masses during the pandemic as a result of the infodemic and information overload created.

In fact, while the paper agrees to the power of social media in informing people with speed and wide reach, it observes that the Abakaliki residents have a sceptical perception of the social media coverage of covid-19. This is evident as their responses corroborated a belief in the anti covid-19 protocols in the social media but still observed many of the safety protocols. All said and done, it can also be concluded that the respondents see social media as a more credible channel of information since it tells them what the mainstream media ignore. A case study here is the social media presentation of the distribution of covid-19 palliatives which the mainstream media, in many occasions, only followed up after the social media has brought it to the public's knowing.

\section{RECOMMENDATIONS}

In the light of the above findings, it is recommended in the first place that users of social media should be wary of social media contents, particularly in the time of crises. In a developing country like Nigeria, it is highly recommended that social media outlets should develop a functional fact-checking app and the government of the day has to come up with regulations, not just to guide the posting of contents on social media but being able to know who posts what on the social media. This will lead to self-censorship for citizen journalists.

\section{Future Research}

It is expected that researchers with similar interest should carry out further studies on the "influence of social media on audience' credibility of mainstream media coverage of covid19 in another setting outside southeastern states of Nigeria".

\section{REFERENCES}

Bittner, J. (1989). Introduction to mass communication. Prentice Hall. England.

Caitlinalder. (2020). Social media and the spread of Covid-19 in Nigeria. Retrieved at https://blogs.bmg.com. 22/4/2021. 3:22am

DC Communicators. (2002). The impact of social media on crisis management. Retrieved at https://www.getproofusa.com/the-impact-of-social-media-on-crisis-management. 5/4/2021. 06:06pm 
Ekwunife R.A., Kalu, O., Ukeje, I.O and Eguavoen, V. (2020). Citizen Journalism and Crisis Management: Nigeria and South Africa. In Farazmand A (ed) Global encyclopedia of public administration, public policy and governance. Springer, https://doi.org/10.1007/978-3-319-31816-5_4119-1

Ekwunife, R. A., Chukwu, C. O., Agha, O.G., Ukeje. I. O and Anih, C.A. (2021). Mass media and politics in Nigeria: The Age-Long War. In Farazmand, A. (ed). Global Encyclopedia of Public Administration, Public Policy, and Governance. https://doi.org/10.1007/978-3-319-31816-5_4344-1

Ekwunife, R.A., Opara, O. A., Akpan, R. E., Sunday, H. T. (2021). ENDSARS protest and centralized police system in Nigeria. In Farazmand A. (ed). Global Encyclopedia of Public Administration, Public Policy, and Governance. Springer Nature. Switzerland. htts://doi.org/10.1007/978-3-319-31816-5 4353-1

Ekwunife, R.A., Robinson, D.F., Ukeje, I.O and Ojiaku, K. (2020). Communication management of COVID-19 in Nigeria. In: Farazmand A (ed) Global encyclopedia of public administration, public policy and governance. Springer. https://doi.org/10.1007/978-3-319-31816-5_4153-1

Ekwunife, R.A., Ukeje, I.O., Ojiaku, K. and Robinson, D. (2020). Bureaucracy and citizen journalism: implication for media and governance in Nigeria. Farazmand A (ed) in Global Encyclopedia of Public Administration, Public Policy and Governance. Switzerland. Springer. http://springer.iqtechnikum.de/referenceworkentry/10.1007/978-3-319-31816-5_3824-1

Kalu, O. and Ekwunife, R. A. (2020). Assessing the Impact of Citizen Journalism on Professional Media Practice in Nigeria: Enugu State in Focus. Ikogho: Education, Social Sciences, Humanities \& Management Sciences Journal- UNIPORT. 19 (1). 627642

NCDC. (2020). Twitter @ NCDCgov. Retrieved 14 May 2020. 3:45 am

Ndolo, I.S. (2011). Media as the fourth estate of the realm: Real or imagined. In Ndolo S. (ed). Contemporary issues in communication and society. Enugu. Rhyce kerex.

Nwakpu, E.S., Ezema, V.O. and Ogbodo, J. N. (2020). Nigeria media framing of coronavirus pandemic and audience response. Health Promote Perspect. 10(3). 192-199.

Oberiri, D.A. (2016). Information communication technology and citizen journalism in Nigeria: pros and cons, Canadian Research \& Development Centre of Science and Cultures. 11 (4). 1-4.

Oberiri, D.A. and Tunca, E. (2019). Social media and crisis management: A review and analysis of existing studies. https/:www.researchgate.net/publication/330468226. 16/06/2021. 09:00pm

Obi-Ani, N.A; Anikwenze, C and Isiani, S.E. (2020). Social media and the covid-19 pandemic: Observations from Nigeria. https://doi.org/10.1080/23311983.2020.1799483. 23/04/2021. 8:00pm

Okunna, C.S and Omenugha, K.A. (2012.) Introduction to mass communication. Enugu. New Generation Books.

Quin, M., Zhang, Y.C. and Su, C.W. (2020). The essential role of pandemics: A fresh insight into the oil market. Retrieved at erl.scholasticahq.com. 22/3/2021. 12:44pm.

Savrum, Y. M., and Leon, M. (2015). The role of the media in conflict, peacebuilding and international relations. International Journal on World Peace, 32(4), 13-34. http://www.rcmss.com

Tankovska, H. (2021). Global Social Network Ranked by Number of Users 2021. Retrieved at statista.com. 30/4/2021. 3:48pm 
WHO, Thompson, W., and University of Melbourne. (2021). Social media \& govid-19: A Global study of digital crisis interaction among Gen Z and Millenials. Retrieved at https://www.who.int. 5/5/21. 06:00pm

Zhaohui, S., Dean, M., Jun, W., Metin, K., Jaffar, A., Sabina, Š., Xiaoshan L., Junaid A., Ali, C., Yuyang, C. and Ling, Y. (2021). Mental health consequences of COVID-19 media coverage: the Need for effective crisis communication practices. Retrieved at doi: $10.1186 / \mathrm{s} 12992-020-00654-4.21 / 04 / 21$ 